IZA DP No. 4906

Property Value Assessment Growth Limits, Tax Base Erosion and Regional In-Migration

Mark Skidmore

Mehmet S. Tosun

April 2010 


\title{
Property Value Assessment Growth Limits, Tax Base Erosion and Regional In-Migration
}

\author{
Mark Skidmore \\ Michigan State University \\ Mehmet S. Tosun \\ University of Nevada, Reno \\ and IZA
}

\section{Discussion Paper No. 4906 \\ April 2010}

IZA

P.O. Box 7240

53072 Bonn

Germany

Phone: +49-228-3894-0

Fax: +49-228-3894-180

E-mail: iza@iza.org

Any opinions expressed here are those of the author(s) and not those of IZA. Research published in this series may include views on policy, but the institute itself takes no institutional policy positions.

The Institute for the Study of Labor (IZA) in Bonn is a local and virtual international research center and a place of communication between science, politics and business. IZA is an independent nonprofit organization supported by Deutsche Post Foundation. The center is associated with the University of Bonn and offers a stimulating research environment through its international network, workshops and conferences, data service, project support, research visits and doctoral program. IZA engages in (i) original and internationally competitive research in all fields of labor economics, (ii) development of policy concepts, and (iii) dissemination of research results and concepts to the interested public.

IZA Discussion Papers often represent preliminary work and are circulated to encourage discussion. Citation of such a paper should account for its provisional character. A revised version may be available directly from the author. 
IZA Discussion Paper No. 4906

April 2010

\section{ABSTRACT}

\section{Property Value Assessment Growth Limits, Tax Base Erosion and Regional In-Migration}

In 1994 a limit on the growth of property values for tax purposes was imposed in Michigan. One consequence of the newly imposed assessment growth cap was an emerging differential in tax prices between potential new property owners and long-time property owners. The purpose of this paper is to examine the impact of this growing tax price differential on migration patterns. Using county level data on migration activity over the 19942006 period, we present evidence that differential tax prices resulting from the assessment growth cap have reduced in-migration.

JEL Classification: $\quad \mathrm{H} 71, \mathrm{H} 73, \mathrm{~J} 61$

Keywords: $\quad$ property tax, tax base erosion, regional migration, Michigan

Corresponding author:

Mehmet Serkan Tosun

Department of Economics

College of Business

University of Nevada, Reno

Mail Stop 0030

Reno, NV 89557

USA

E-mail: tosun@unr.edu 


\section{Introduction}

With the passage of Michigan’s Proposal A in 1994, a property value assessment growth limit ${ }^{1}$ was implemented which restricts the growth of property valuation for tax purposes to the lesser of rate of inflation or five percent. ${ }^{2}$ Since that time, every year local authorities are required to report for each property within their jurisdiction the actual state equalized value $(\mathrm{SEV})^{3}$ as well as taxable value (TV). In 1994 each property's state equalized value equaled its taxable value. Through time, however, due to rapidly rising housing prices the growth of SEV has outpaced the growth of TV, resulting in tax base erosion. ${ }^{4}$ Further, there is significant variation across communities in the rate at which TV has fallen behind SEV. To illustrate the differences across the state in tax base erosion, consider the ratio of state equalized value to taxable value (SEV/TV) for all Michigan counties. According to the Michigan Department of Treasury State Tax Commission, in 2006 the average SEV/TV for all counties was 1.3. Leelanau County had the highest ratio of state equalized to taxable value (1.75) and Midland County had the lowest ratio of state equalized to taxable value (1.15). Figure 1 shows how SEV/TV varies across Michigan counties, but the story of tax base erosion across regions requires some explanation. Consider the lake counties in the northwest region of the Lower Peninsula. This region experienced substantial growth in prime lakefront property values, and this has led to significant tax base erosion. On the other hand, Bay and Genesee counties in eastern Michigan have experienced very slow growth in property values due to poor economic conditions, and thus have experienced relatively little tax base erosion resulting from the taxable value cap. In contrast, the counties surrounding Grand Rapids have experienced population growth and a substantial amount of new construction, which has expanded the tax base. Like Bay and Genesee Counties, these counties have experienced

\footnotetext{
${ }^{1}$ Such limitations have been referred to as "assessment growth caps", "taxable value caps”, "assessment growth limits", or property tax assessment limits". These terms are used interchangeably throughout the manuscript.

${ }^{2}$ Feldman, Courant, and Drake (2003) provide an excellent review of property taxation in Michigan.

${ }^{3} \mathrm{SEV}$ is equal to one half of estimated market value.

${ }^{4}$ In 2006 housing prices began to fall across the state.
} 
relatively little tax base erosion, but the underlying economic and demographic conditions are very different. The Grand Rapids area has experienced significant new residential development and this has served to keep tax base erosion in check. Bay and Genesee Counties, however, have experienced long-term economic decline and flat housing prices. In this region, tax base erosion is limited because housing prices have been stable or in decline. It should also be noted that over the past two years average property values in Michigan have actually declined so that tax base erosion is now being reversed.

According to a new report by the Lincoln Institute of Land Policy (Haveman and Sexton, 2008), property value assessment growth limits exist in 19 states and the District of Columbia, of which 15 are imposed statewide. ${ }^{5}$ A number of these limitations were imposed in the 1970s and 1980s in the wake of the tax revolt. However, in response to rapidly rising property values across the nation during the late 1990s and running through 2007, interest among policymakers in assessment growth limits was renewed and several states have imposed new restrictions. ${ }^{6}$ Although property tax limitations generally and assessment growth caps specifically has received the attention of researchers, several important dimensions of this particular type of property tax limitation remain largely unexplored. In particular, the objective of this research is to determine the degree to which tax base erosion resulting from the taxable value cap may have affected regional migration patterns. A key feature of the Michigan's taxable value cap is that upon sale of a property, the taxable value increases to state equalized value. What has become known as the "pop up" has resulted in a growing tax price differential between long-time and new property owners. We therefore expect tax base erosion resulting from the taxable value cap to discourage in-migration (due to the high cost of public services imposed on new property owners) and deter out-migration (due to the substantial loss in the tax benefit associated with moving). To our knowledge, the relationship between taxable value caps and migration decisions has not yet been

\footnotetext{
${ }^{5}$ We note that Michigan's assessment growth cap applies to all property types, whereas in many states the assessment growth caps apply to residential property only.

${ }^{6}$ Illinois and Washington are two recent examples.
} 
examined by researchers. In this paper, we focus on in-migration although we also present some analysis of out-migration as well.

The remainder of the paper is organized as follows. In the next section we provide an outline of Michigan's property value assessment growth limit and other pertinent property tax policies. We then provide a review of the most relevant research regarding property value assessment growth limits as well as related research on migration patterns. In section IV, we present a simple framework to illustrate the determinants of tax base erosion and show how tax prices are altered as result of tax base erosion. Section V presents the data and empirical analysis, and section VI concludes.

\section{The Property Tax in Michigan}

During the latter part of the $20^{\text {th }}$ century Michigan legislators as well as citizens via referenda processes have implemented several measures designed to protect targeted property owners from the property tax. In addition to the taxable value cap, it is important to also note other key property tax policies such as the homestead exemption, the income tax credit, the mobile home park exemption, and the Headlee amendment. ${ }^{7}$ Of particular relevance to the present study is the homestead exemption which was implemented jointly with the taxable value cap under Proposition A, and Headlee amendment which was imposed in 1978.

In Table 1 we present average statewide property tax millage rates from 1990 through 2006. Over this period, the only major change occurred in 1994 with the passage of Proposal A. Proposal A reduced average millage rates for all homestead properties by 34 mills. This has become known as the "homestead exemption." The state government then added a 6 mill state education tax and increased sales taxes and cigarette taxes to provide for the financing of k-12 public education. With the exception of this major policy shift, average millage rates across the state have been stable, although it should be noted that property tax rates vary considerably across

\footnotetext{
${ }^{7}$ These policies are clearly articulated and discussed in Feldman, Courant, and Drake (2003).
} 
jurisdictions. This stability is largely due to the implementation of the Headlee Amendment in 1978, which restricts property tax revenue growth to the rate of inflation plus new construction. Importantly, under Headlee any potential revenue increases beyond the limit resulting from property value growth would require rate reductions to bring revenues into line with the revenue growth restriction. This feature of the property tax revenue growth limit is known as the “Headlee Rollback.” Local residents can, however, choose to exceed the Headlee limitation by referendum. Once the taxable value cap was imposed, Headlee Rollbacks were greatly reduced in numbers and magnitudes.

Each year the State of Michigan Department of Treasury provides estimates of tax expenditures for all major sources of tax revenues. The single largest property tax expenditure arises from the taxable value cap, and this is followed by the homestead exemption. Tax exempt property is a distant third. These three property tax expenditures make up more than three quarters of the total. As of 2007, the tax expenditure associated with the taxable value cap had become so large that its repeal, holding total property tax revenues constant, would result in a reduction in the statewide average statutory tax rate of 23 percent. In some counties the average statutory tax rate could be reduced by more than 40 percent.

The Citizens Research Council (2001) was among the first organizations in Michigan to highlight the growing differential between SEV and TV. In a statewide summary, they showed how the ratio of taxable value to assessed value differed across regions and across types of property. SEV/TV for commercial and industrial property in 2000 remained relatively high at 1.15 and 1.08, respectively. SEV/TV for agricultural, timber cutover and developmental properties, however, had all risen above 1.45. SEV/TV for residential property had dropped to about 1.22. ${ }^{8}$ While the Citizens Research Council report highlighted the potential shift in tax

\footnotetext{
${ }^{8}$ The Citizens Research Council reports on changes in TV/SEV. We use SEV/TV to be consistent with our empirical results and interpretations later in our paper. These numbers are simply the inverse of the numbers reported in Citizens Research Council (2001). For purposes of interpreting estimation results, in our empirical analysis we estimate the determinants of the inverse of TV/SEV, or SEV/TV.
} 
burdens across property types, it did not provide a discussion of the broader implications regarding the horizontal and vertical inequities that were beginning to emerge. Given that taxable value caps have now existed in a number of states over a period of rapidly rising property values, there is now a growing body of research that has examined the effects of property value assessment growth limits, and it is on this work that we now focus our attention.

\section{Literature Review}

The early empirical research on property tax limits, including property value assessment growth constraints tended to focus on determining the degree to which these emerging fiscal institutions actually constrained property tax revenue growth. ${ }^{9}$ More recently, however, researchers have turned their attention to the distributional consequences of property value assessment growth limits. In 2006 the National Tax Journal devoted an entire issue to the property tax, and several articles evaluate the potential consequences of property tax limitations, and in particular the peculiar distributional consequences of property value assessment growth limits. We review several key articles from this issue as well as some other recent research.

Dye, McMillen, and Merriman (2006) assess the implications of the recently imposed assessment growth cap which was introduced in Cook County, Illinois. They demonstrate that a taxable cap of this nature cannot be introduced without having comparative increases in taxes for others. For example, a taxable value cap that protects residential owners as in Cook County, Illinois will simply lead to increased taxes for industrial and commercial property owners. They also show that homeowners with property that appreciates at a rate less than the cap will experience higher rates to make up for those who are protected. Of particular relevance to the present study, they indicate that the "extent that the cap reduces the property tax payments for

\footnotetext{
${ }^{9}$ See Dye and McGuire and McMillen (2005), Mullins and Joyce (1996) and Skidmore (1999) for a review of this literature.
} 
rapidly growing areas... may discourage mobility, since the expanded exemption is lost when real estate is sold, and, thus, may decrease the efficiency of the residential real estate market.”

Dye and McMillen (2007) extended work of Dye, McMillen and Merriman (2006) by developing a formal theoretical framework to evaluate the effects of assessment caps on property taxes. Two key conclusions are: 1) "reassessment upon sale can make it expensive for homeowners to move, and may depress real estate markets”, and 2) the assessment limits can "lead to higher taxes for some property owners whose assessments had been lowered." To illustrate, Dye and McMillen report that in Minnesota 78 percent of all residential homesteads had to pay a higher tax as a result of taxable value cap than they would have had if taxable values remained unrestricted. ${ }^{10}$ Dye and McMillen conclude, "taxes must rise for some properties in order to provide relief to others" and "it is obvious...that properties in the cap-eligible group with appreciation rates below the assessment cap will always come out behind.”

The recent work of Muhammad (2007) evaluates the horizontal and vertical inequities resulting from the District of Columbia's taxable value cap policy which was imposed in 2002. District of Columbia's tax cap policy (TCP) imposed a property value assessment growth limit set at 12 percent annually between 2001 and 2005 and 10 percent thereafter. Over the 2001-2007 period, median homestead property values more than tripled in the District of Columbia (\$128,499 to $\$ 400,050)$, and this represented an average annual increase of 20.8 percent. By 2007 the median property's final taxable value differed from the actual market value by over 60 percent. Muhammad demonstrates the degree of horizontal and vertical inequity resulting from the assessment growth limit using data on taxable value and estimated market value for all homes in the District of Columbia. He finds that for homesteads with a value of $\$ 600,000$, the effective millage rate can be as high as $\$ 0.79$ or as low as $\$ 0.01$.

\footnotetext{
${ }^{10}$ Dye and McMillen refer to a November 2006 presentation given by Mark Haveman and Paul Wilson at the Lincoln Institute of Land Policy.
} 
In 2008 the Lincoln Institute of Land Policy (Haveman and Sexton, 2008) published a comprehensive report on property tax assessment limits and their use across the U.S. states. The report covers the institutional/legal aspects of such limits, the implications for the tax base and local government autonomy, equity issues, and the inefficiencies that arise. The report concludes by offering potential alternatives to provide property tax relief to those in need. The authors assert that property tax assessment limits are “...the least effective, least equitable, and least efficient strategies available for providing tax relief.”

We have focused on the most recent literature evaluating the distributional consequences of property value assessment growth limits. We note, however, that the work of Anderson and McGuire (2007), Giertz (2006), Bowman (2006), and Youngman (2007), among others provide excellent discussions of important issues surrounding the property tax and property tax limitations, including assessment growth caps. There is also a body of research that has examined the effects of assessment growth caps on mobility, and more generally there is an extensive body of work that has examined interstate migration patterns. We discuss this research next.

\section{Mobility and Migration}

In a recent study, Wasi and White (2005) examined the potential lock-in effect for housing choice from Proposition 13, using data from 1970 to 2000, and found a significant effect. The average tenure length of California homeowners increased by 0.66 years or six percent relative to homeowners in Texas and Florida, which were chosen as comparison states. The increase was as high as two to three years in places like San Francisco and San Jose, areas in which stable homeowners received the highest subsidies from the assessment growth limit embedded in Proposition 13. ${ }^{11}$ Ferreira (2004) also examined residential mobility after Proposition 13, but focused on the two amendments that allowed transferability of the implicit tax

\footnotetext{
${ }^{11}$ Nagy (1997) also examined the change in household mobility after California’s Proposition 13, using the Annual Housing Surveys from 1975, 1978 and 1982. While he found evidence of a decline in mobility, this was not significantly different from similar declines in other parts of the country.
} 
benefits to a new home for head of households who are 55 or older. In a comparison with two age groups, he found that mobility for the 55-year old group is about 25 percent higher than the mobility for the 54-year old group. In summary, these studies present empirical evidence for a link between California’s assessment growth limit and household mobility.

Another strand of the migration literature examines whether state fiscal variables affect interstate migration patterns. The study by Cebula and Alexander (2006) examined the impact of economic and non-economic factors on the net state in-migration between 2000 and 2004. They found government spending on primary and secondary education, and state individual income tax burden as positive and negative factors, respectively. Clark, Knapp and White (1996) found that location characteristics, including fiscal variables, are important determinants of elderly interstate migration, but the explanatory power of those variables declines with older age groups. Conway and Houtenville $(1998,2001)$ used state-level data to examine determinants of elderly interstate migration and found that fiscal variables play an important role in both in-migration and outmigration. Somewhat related is the work of Farnham and Sevak (2002) who provided evidence from the Health and Retirement Study (HRS) that moving households reduce their property tax liability on average by $\$ 115$. This suggests that property taxation plays a role in decisions to move.

In this section we provided a discussion of the literature on property value assessment growth caps and their distributional consequences, and the relationship between state/local fiscal variables and mobility and migration. While the mobility research is most closely related to the present work, to our knowledge no studies have examined the potential impact of the taxable value cap on regional migration patterns. We now turn to the theoretical considerations of assessment growth caps in the context of tax base erosion, tax price differentials between longtime property owners and potential new property owners, and migration patterns.

\section{Theoretical Considerations-Tax Base Erosion and In-Migration}


When the Michigan assessment growth limit was imposed in 1994, aggregate taxable value for each individual property in the state equaled its state equalized value. ${ }^{12}$ From 1995 and on, the growth of taxable value for any existing property not sold during the period is allowed to grow at the rate of inflation as measured by the consumer price index or five percent, whichever is lower. If the state equalized value of properties in a jurisdiction increase at a rate faster than the inflation, the ratio of state equalized value (SEV) to taxable value (TV) will begin to rise. An exception is when a property is sold: in this case TV returns to SEV. If one aggregates to the county level, changes over time in SEV/TV will depend on the rates of change in property turnover, property prices, and housing stock. However, property turnover, property prices, and housing stock depend on economic and demographic factors.

We consider a range of socioeconomic variables that vary by county and over time may determine changes in property turnover, property prices, and housing stock and thus tax base erosion: Percent of population between the ages of 0 and $17(0-17)$, percent of population between 18-24 (18-24), percent of population between 25-44 (25-44), percent of population between 45-64 (45-64) $)^{13}$, the marriage rate (MARRIAGE), the divorce rate (DIVORCE), the mortality rate (MORTALITY), the birth rate (BIRTH), per capita income (PCINC), the rate of unemployment (UNEMP), manufacturing employment (MANU), government employment (GOV), retail employment (RETAIL), and all other employment (OTHER). ${ }^{14}$

Age distribution determines housing turnover as well as housing demand, and therefore may affect SEV/TV. For example, generally the young are more likely to move than middle-age or older demographic groups. Major life changing events such as marriage, a birth, divorce, and family loss determine both the rate of turnover and housing demand. To illustrate, the work of

\footnotetext{
${ }^{12}$ State equalized value is defined as 50 percent of estimated market value.

${ }^{13}$ The percent of population that is over the age of 65 is omitted in our empirical analysis to avoid perfect multicollinearity.

${ }^{14}$ An advantage of county level data is that annual series are available for a wide range of socioeconomic and demographic variables, which are unavailable for smaller local government jurisdictions. It must be acknowledged that a disadvantage of using county level data is that aggregation to the county level abstracts from tax base erosion differentials across communities within a county.
} 
Yu and Liu (2007) shows that divorce increases the number of homes occupied. While their focus was on evaluating the environmental impact of divorce, there is a link to tax base erosion: Changes in divorce rates can lead to changes in the demand for homes and housing turnover. We therefore hypothesize that variables that capture major life events are negatively correlated with SEV/TV. We also suggest that these life change variables are appropriate instruments and can be used to identify the causal relationship between tax base erosion and migration activity. The validity of these variables as instruments is evaluated and discussed later.

Economic conditions are also important. We expect counties with increasing income and reductions in unemployment to experience greater tax base erosion. Also, the expected relationship between employment and SEV/TV is mixed: Counties experiencing declines in manufacturing employment and other employment categories may experience higher turnover rates, but home values may also be falling. The expected impact on SEV/TV is ambiguous.

Tax base erosion results in higher tax prices for potential new property owners, relative to long-time property owners. Prior to the imposition of the assessment growth cap in 1994, the Headlee revenue growth limit required property tax rate rollbacks (Headlee rollbacks) whenever revenues grew faster than the rate of inflation plus new construction. In fact, Headlee rollbacks were very common prior to 1994, and this insured that all property owners enjoyed lower tax rates as property values grew. After 1994, however, rollbacks were reduced both in number and magnitude. Thus, over time new property owners were increasingly required to pay higher tax prices than long-time property owners. Increasing tax prices for new property owners raises the cost of public services for this group, and this has the potential to reduce in-migration. The impact of the assessment growth cap, in part, depends on the time preferences and the expected time horizon of property ownership. A new property owner with a low discount rate and who expects to hold onto the property for many years may perceive a long-run benefit of the assessment growth cap: He may be willing to pay more today knowing that he is protected from future increases in taxes. On the other hand, new property owners with a high discount rate who 
expects to own the property for only several years will not enjoy the potential tax benefits associated with the assessment growth cap. Therefore, the overall effect of the assessment growth cap on in-migration is indeterminate; however, we hypothesize that in-migration will be reduced by the assessment growth cap particularly in areas where the tax prices for new property owners could have been substantially lower in the absence of the assessment growth cap. ${ }^{15}$ All else equal, in-migration could be affected in counties that experienced significant tax base erosion. ${ }^{16}$ We now turn our attention to a critical issue in our evaluation of tax prices and inmigration patterns - endogeneity.

In order to determine whether tax base erosion as measured by $\frac{\mathrm{SEV}_{\mathrm{it}}}{\mathrm{TV}_{\mathrm{it}}}$ reduces inmigration, we must properly address the issue of endogeneity. While our interest is in determining the effect of tax base erosion on in-migration, it must be acknowledged that migration activity potentially affects turnover rates and thus $\frac{\mathrm{SEV}_{\mathrm{it}}}{\mathrm{TV}_{\mathrm{it}}}$. In order to estimate the effect of $\frac{S E V_{i t}}{T V_{i t}}$ on in-migration, we must identify instruments and use appropriate estimation procedures to address endogeneity. Keeping in mind that our ultimate goal is to examine the relationship between tax base erosion and in-migration, consider the following first-stage reduced form tax base erosion equation:

$$
\ln \left(\frac{S E V_{i t}}{T V_{i t}}\right)=a_{n}\left(\ln \left(X_{i t}\right)\right)+b_{n}\left(\ln \left(L I F E_{i t}\right)\right)+\mu_{i}+\varepsilon_{i t}
$$

\footnotetext{
${ }^{15}$ Recall that in absence of the assessment growth cap, areas of high property value growth would have experience tax rate rollbacks under the Headlee revenue growth limit.

${ }^{16}$ Note that the difference in the tax rates for new comers and current residents is based on the average rate for existing residents. The marginal difference between a new comer and a given current resident depends on the length of time a current resident has lived in his/her home. In some cases, an existing resident who has lived in his/her home since 1994 (the date the assessment growth limit was imposed) might enjoy a tax bill that is half that of new comers for similarly valued properties.
} 
where $X_{i t}$ is a vector of exogenous explanatory variables as described above, and LIFE $E_{i t}$ represents a vector of life change event variables, $\mu_{\mathrm{i}}$ are county fixed effects, and $\varepsilon_{\mathrm{it}}$ is the error term. In some specifications we also include time indicator variables and county-specific time trends.

The coefficients from this regression are generated from the within county changes in the variables across Michigan counties over the 1994-2006 period. These estimates are provided for the interested reader in the Appendix A. As we discuss in more detail in the empirical section, the vector $L_{I F E}$ and/or subsets of variables in this vector serve as appropriate instruments in our econometric analysis.

While we are also interested in the degree to which the taxable value cap has affected out-migration, we focus on in-migration because our instruments are most compelling in the case of in-migration (the in-migration decision is made by those not currently living within a given jurisdiction). In order to estimate the impact of tax base erosion and on in-migration, we must identify appropriate instrument(s) in order to test for endogeneity, and if present use appropriate estimation procedures. Appropriate instruments must be correlated with SEV/TV but not be directly correlated with in-migration. Our analysis suggests that life change events as characterized by MARRIAGE, BIRTH, DIVORCE and MORTALITY are appropriate instruments. The identification strategy is based on the idea that these life change variables trigger turnover rates and demand for housing, thereby affecting the degree of tax base erosion, but these variables are not direct determinants of in-migration. The analysis also shows that at least some of these variables are strong instruments in that they are statistically significant and meaningful determinants of tax base erosion, but these variables do not directly determine inmigration. Also, as discussed in greater detail later, we use alternative combinations of the instruments to examine the sensitivity of our findings. Although we find no empirical evidence to support the following notion, one could argue that, particularly, decisions to marry, divorce or child birth are influenced by tax base erosion or other economic factors that influence both tax 
base erosion and in-migration decisions that are not controlled for in our econometric analysis. ${ }^{17}$ If this is the case, these variables would not serve as appropriate instruments.

To examine the appropriateness of our instruments, we use the Sargon's Test of Overidentifying Restrictions. Using different sets of instruments, in each case we fail to reject the null hypothesis that our instruments are valid. These examinations suggest that we have identified appropriate instruments for the measure of tax base erosion for in-migration analysis. ${ }^{18}$ We also conduct similar tests in the context of out-migration, and again these examinations indicate that we have identified appropriate instruments, although we acknowledge we a have a weaker theoretical case with out-migration.

Given that we have appropriate instruments, we next conduct a Hausman test of endogeniety. If the Hausman test of endogeneity indicates that endogeneity is a concern, we must use a simultaneous equation procedure. To complete the Hausman test, the residual generated from equation (2) is included as an explanatory variable in the in-migration regression. If the measure of tax base erosion is endogenous, then the coefficient on this residual should be significantly different from zero. The Hausman test for examining the endogeneity of SEV/TV suggests that the null hypothesis that SEV/TV is exogenous is rejected. We therefore proceed with estimating the in-migration equation with a correction for simultaneity using a two-stage least squares procedure, but for comparison we also present regressions without the correction for simultaneity.

Before presenting the specification of the second stage regression some additional explanation is required. The specification we use is guided by the following framework. Let inmigration be influenced by $\pi$, the tax price faced by potential new property owners and a vector $\mathrm{X}$, a series of economic and demographic factors that vary within counties over time that may

${ }^{17}$ Our analysis also suggests that these instruments are appropriate for out-migration as well. ${ }^{18}$ Specifically, we examined the following combinations of instruments: 1) DIVORCE, MARRIAGE, MORTALITY, and BIRTH; 2) MORTALITY, BIRTH, MARRIAGE; 3) MORTALITY, BIRTH; and 4) MORTALITY. We also included TV(-1) as an instrument in a different set of estimations. In all combinations, the null hypothesis that our instruments are valid is not rejected. 
affect in-migration. Our primary interest is in determining the degree to which in-migration is affected by the tax price faced by the potential in-migrant, which depends on the degree of tax base erosion as measured by SEV/TV However, the tax price faced by new comers is also determined by the statutory tax rate as well as the degree to which housing prices, $\mathrm{P}$, differ from two times SEV. ${ }^{19}$ Consider the following equation to illustrate the tax price faced by a potential new property owner. Let $\pi_{\mathrm{it}}$ be the tax price faced by a property owner in county $\mathrm{i}$ in period $\mathrm{t}$ : $\pi_{i t}=r_{i t}\left(\frac{P_{i t}}{2 \cdot S E V_{i t}}\right)\left(\frac{S E V_{i t}}{T V_{i t}}\right)$

where the $\mathrm{r}_{\mathrm{it}}$ is the statutory tax rate and $\mathrm{P}_{\mathrm{it}}$ is the ratio of the average housing price in the county. Our core hypothesis is that, holding $\mathrm{r}$ and $\mathrm{P} /(2 \cdot \mathrm{SEV})$ constant, tax base erosion as measured by SEV/TV leads to a higher tax price for new comers and thus deters in-migration.

This tax price framework informs the econometric specification because equation (2) makes clear that the tax base erosion (SEV/TV) component of the tax price will need to be isolated to estimate its effect on in-migration. Previous research evaluating the role of tax policy on migration patterns has used several different specifications. Conway and Rork (2006), for example, use the elderly migration rate as the dependent variable in a linear specification. On the other hand, Conway and Houtenville (2001) use migration flow as the dependent variable in a logarithmic specification. Cebula (1990) and Cebula and Alexander (2006) also use migration flow as the dependent variable but in a linear framework. In the present study, it is convenient to use a semi-logarithmic specification in order to separate the components of $\pi$ and thus isolate the effect of tax base erosion associated with the taxable value cap. The core in-migration specification is therefore:

Inmig $_{i t}=a_{i}+b \ln \left(r_{i t}\right)+c \ln \left(\frac{P_{i t}}{2 \cdot S E V_{i t}}\right)+d \ln \left(\right.$ predicted $\left.\frac{S E V_{i t}}{T V_{i t}}\right)+e^{\prime} \ln \left(X_{i t}\right)+e_{i t}$

\footnotetext{
${ }^{19}$ Recall that SEV is defined as one half of market value.
} 
where Inmig ${ }_{i t}$ is the migration rate for county $\mathrm{i}$ in period $\mathrm{t}$. In all regressions we control for county fixed effects $\left(\mathrm{a}_{\mathrm{i}}\right)$ and a vector of exogenous factors, $\mathrm{X}_{\mathrm{it}}$, that vary within counties over time that may affect in-migration. In different sets of regressions we include a set of time indicator variables and county-specific time trends to control for $r_{i t}, \frac{P_{i t}}{S E V_{i t}}$ and other possible omitted trends and factors that might be correlated with tax base erosion. ${ }^{20}$ The variable predicted $\frac{S E V_{i t}}{T V_{i t}}$ represents the predicted value of $\left(\frac{S E V_{i t}}{T_{i t}}\right)$ generated from the first-stage regression and its effect on in-migration measured by the coefficient $\mathrm{d}$.

We use the two-stage generalized method of moments estimation procedure which is robust to both heteroskedasticity and autocorrelation. The interested reader may review the first stage tax base erosion regression results in the Appendix A, but these are not discussed in detail. We note, however, that two of the variables that indicate major life events (MARRIAGE and MORTALITY) are statistically significant three of four specifications. The exception is in the regression in which when both the time indicator variables and county-specific time trends are included in the specification. Higher rates of marriage and mortality result in less tax base erosion, perhaps because the rate of home purchases and property turnover is higher. These estimates provide some assurance that these variables will serve as strong instruments. Further, an F-test shows that the combination of the instruments is jointly significant in all regressions, and is thus effective as a set.

Previous studies of migration flows in an interstate context have focused on the role of amenities such as weather conditions, etc... which are largely fixed over our timeframe. We acknowledge that amenities play an important role in intra-state migration patterns. However,

\footnotetext{
${ }^{20}$ Unfortunately, we do not have a reliable time varying county level measure of $\mathrm{P}_{\mathrm{it}}$. Also, in specifications available from the authors upon request we explicitly include the statutory tax rate (r) as an explanatory variable, but the inclusion of this variable has virtually no effect our core findings, and $r$ is never statistically significant. We omit $r$ in the specifications presented due to concerns about endogeneity of the tax rate variable.
} 
such amenities are largely fixed over the period of analysis and therefore we control for amenity factors with county fixed effects. In addition, in some specifications we included time indicator variables and county-specific time trends to examine the robustness of our findings. This specification allows us to focus on conditions that have changed within counties over time that may affect in-migration: Socio-economic and fiscal conditions. Additional details regarding the methods of analyses used are discussed next.

\section{Empirical Analysis}

The data are a panel of 982 observations $^{21}$ that include all 83 Michigan counties for years 1994 through 2006. We estimate fixed effects regressions using a cluster approach in which we cluster our standard errors at the county level to address temporal autocorrelation. Cluster-standard errors perform well when the number of clusters is reasonably large (Bertrand et. al., 2004; Kezdi, 2004). However, note that we also used as an alternative estimation approach spatial econometric methods in the context of panel data. In regressions that are not presented but are available upon request from the authors, we find that these estimates are qualitatively similar to those presented here. ${ }^{22}$ Below, we present the regression results which examine the relationship between tax base erosion and in-migration.

Summary statistics for these and all variables used in the estimations are presented in Table 2, and detailed definitions and sources of all variables used in the analysis are shown in the Appendix B. The regressions in columns 1-4 of Table 3 present the estimates without addressing

\footnotetext{
${ }^{21}$ We do not have a complete panel due to some missing/unreported data in our employment variables. In addition the number of observations decreases to 812 in the two-stage least squares estimates because of missing data in the life change variables.

${ }^{22}$ While spatial considerations are important, we do not focus on this issue for several reasons. First, the fixed effects account for any spatial patterns that are fixed over time. Second, we believe temporal correlation is a more serious concern. Last, in our in-migration regressions endogeneity is a potentially serious econometric issue. We therefore believe a fixed effects procedure that addresses temporal serial correlation, heteroskedasticity, and endogeneity is the best overall econometric approach in the context of this study.
} 
endogeneity, whereas columns (5-8) present the two-stage least squares regressions, using as instruments the major life change variables: MARRIAGE, BIRTH, DIVORCE, MORTALITY.

The results presented in columns (1-4) consistently show that the $\frac{\mathrm{SEV}_{\mathrm{it}}}{\mathrm{TV}_{\mathrm{it}}}$ variable affects in-migration negatively. These regressions provide evidence that tax base erosion is inversely correlated with in-migration. However, the standard error of the tax base erosion variable is somewhat sensitive to the inclusion of time indicator variables and county-specific time trends. $\frac{\mathrm{SEV}_{\mathrm{it}}}{\mathrm{TV}_{\mathrm{it}}}$ maintains statistical significance when either time indicator variables or county-specific time trends are included, but the coefficient falls below the standards of statistical significance when both are included. Regardless, the magnitude of the coefficient is reasonably consistent across this set of regressions. It is not too surprising that once statewide trends and countyspecific trends are controlled for that precision of the estimates fall. Overall, these estimates suggest that counties with greater tax base erosion experience less in-migration, controlling for other factors. While the inclusion of count-specific time trends reduces the potential for omitted variable bias and endogeneity, these estimates may still be plagued by simultaneity. We therefore present a series of two-stage least squares estimates in columns 5-8.

The two-stage least squares estimates are very similar accept the magnitude of the coefficient on $\frac{\mathrm{SEV}_{\mathrm{it}}}{\mathrm{TV}_{\mathrm{it}}}$ is now considerably larger, and indication that any potential bias resulting from simultaneity appears to be toward zero. When both time indicator variables and countyspecific time trends are included in the regressions, the coefficient on $\frac{\mathrm{SEV}_{\mathrm{it}}}{\mathrm{TV}_{\mathrm{it}}}$ again falls below typical standards statistical significance. 
To provide a sense of the estimated effects of tax base erosion on in-migration, consider the following calculation. Based on the coefficient estimate on $\ln \left(\frac{S E V_{i t}}{T V_{i t}}\right)$ from column (6), a one standard deviation increase in $\frac{\mathrm{SEV}_{\mathrm{it}}}{\mathrm{TV}_{\mathrm{it}}}$ from its mean value is predicted reduce in-migration by about 32 percent. $^{23}$ A one standard deviation increase in $\frac{\mathrm{SEV}_{\mathrm{it}}}{\mathrm{TV}_{\mathrm{it}}}$ represents an 17 percent differential in tax price between a older protected homeowner and a potential new homeowner. In this context, the estimated in-migration response seems quite large. The coefficient estimates generated from the regressions that do not correct for endogeneity (columns 1-4) are much smaller, however. Based on these coefficients, a one standard deviation increase in $\frac{\mathrm{SEV}_{\mathrm{it}}}{\mathrm{TV}_{\mathrm{it}}}$ is predicted to reduce in-migration between 8 and 15 percent. Although our examinations suggest that our instruments are valid and that endogeneity is present, we still have concerns about the instruments. Furthermore, as illustrated above the instrumental variables approach generates estimates that seem too large. For these reasons, we tend to favor the more conservative OLS estimates.

Turning to the control variables, we see that the coefficients on per capita income are positive and consistently significant. The coefficients on unemployment are negative but not always significant. Similarly, some of the coefficients on the employment variables, particularly retail and other employment, are consistently negative and sometimes significant. While a highconcentration of a particular population age group could be a contributing factor to county in-

\footnotetext{
${ }^{23}$ From column (6), the coefficient on $\ln (\mathrm{SEV} / \mathrm{TV})$ is 0.12 . The mean value and standard deviation of SEV/TV are 1.22 and 0.167 , respectively. The average annual in-migration rate is 0.048 . Therefore, a one standard deviation increase in SEV/TV is predicted to reduce in-migration by the coefficient estimate multiplied by the (initial $\ln (\mathrm{SEV} / \mathrm{TV})$ minus new $\ln (\mathrm{SEV} / \mathrm{TV})$ ), or $0.12 \mathrm{x} 0.127=0.0152$. This is roughly a 32 percent reduction in in-migration.
} 
migration (e.g. retiree in-migration to counties with more elderly population), we generally do not find the demographic variables to be significant determinants of in-migration.

\section{Robustness}

To examine the robustness and sensitivity of the core finding, we consider a range of issues. First, in regressions not reported but are available from the authors upon request, we included the aggregate statutory tax rate as an additional explanatory variable in the regressions. ${ }^{24}$ None of our core conclusions are altered with the inclusion of the statutory rate variable. We also examined the effect of $\frac{\mathrm{SEV}_{\mathrm{it}}}{\mathrm{TV}_{\mathrm{it}}}$ interacted with the statutory rate variable, treating the interaction term as endogenously determined. In these regressions we find that the effect of tax base erosion on in-migration is most pronounced in areas with relatively high tax rates. ${ }^{25}$ In other regressions we use lagged explanatory variables; again our core finding is unaltered. We examined the sensitivity of the two-stage least squares estimates by using different combinations of instruments. These findings are generally consistent with those presented here. We estimated two alternative specifications that have been used in previous research on migration: 1) a linear specification; and 2) a log-log specification. Again, our core findings are robust to these considerations. Finally, we examined the effect of tax base erosion on in-migration in the context of a system of equations that include in-migration, out-migration, and new construction. We estimate this system using a three-stage least squares estimation procedure, and these are available from the authors upon request. ${ }^{26}$ The in-migration results are very similar to those presented here.

\footnotetext{
${ }^{24}$ We exclude the statutory rate variable in the regressions we present because we recognize the difficulties associated with the potential endogeneity of property tax rate changes and migration decisions.

${ }^{25}$ Conversely, one could interpret this result as indicating the higher tax rates reduce in-migration more in areas where tax base erosion is highest. These results are available upon request from the authors.

${ }^{26}$ One drawback of this econometric approach, however, is that we are unable to address autocorrelation with the clustering technique. Thus, in these estimates the standard errors are biased downward, leading to inflated t values.
} 
Although the focus of this research is on the relationship between tax base erosion and inmigration, in Appendix $\mathrm{C}$ we also present a series of out-migration regressions. This set of regressions is analogous to those in Table 3 except that the dependent variable is out-migration. We are more cautious in our interpretation of these findings because the life change variables we use as instruments are arguably not purely exogenous to out-migration decisions. ${ }^{27}$ The set of regressions reveals no consistent relationship between out-migration and tax base erosion, although we note that our most rigorous specification in which we correct for simultaneity and control for time indicator variables and county-specific time trends indicates that tax base erosion has reduced out-migration.

\section{Conclusion}

The work presented in this paper evaluates the degree to which tax base erosion and corresponding differential in tax prices between potential property owners and long-time property owners has affected in-migration. To our knowledge, this is the first such formal analysis of the migration effects of differential tax base erosion resulting from a property value assessment growth cap. Other factors such as changing economic circumstances have arguably played a much stronger role in location decisions. On the margin, however, home seekers appear to be influenced by the peculiar fiscal environment associated with property tax assessment growth limits.

Over the past two and half years, home values have fallen across Michigan, but the rate of decline varies across regions. The analysis presented here may also be useful for understanding the differential impacts of falling home values in terms of reversing the tax base

\footnotetext{
${ }^{27}$ Although we are cautious with our interpretation, note that Sargon’s Test of Overidentifying Restrictions suggests that the instruments are valid for the out-migration analysis. The Hausman test provides evidence of endogeneity in the context of out-migration. Thus, instrumental variable procedures are appropriate.
} 
erosion. ${ }^{28}$ Legislators, aware of the high effective property tax rates associated with tax base erosion caused by the taxable value cap, have considered implementing a new income tax credit for new homeowners to offset the "pop up" property tax increase. While not an ideal solution, the debate suggests that legislators are becoming aware of the implications of the taxable value cap. In Michigan, however, substantial revisions or possible repeal of the taxable value cap would require voter approval.

One implication of falling home values is that the distortions caused by the taxable value cap are being reduced. It would seem then that analysis of such distortions is less relevant. However, our examination sheds light on the effects of the taxable value cap at an opportune time. Reductions in property values mean that long-time homeowners who might otherwise have much to lose by the elimination of the taxable value cap may not object to its repeal in the current environment. In a political economy framework, there is no time better than now to consider the elimination of poorly conceived constraints such as the taxable value cap. In 1994, the taxable value cap was approved by voters under the premise that it would further limit property taxation. However, it is very likely that many voters did not fully understand that such a constraint would ultimately lead to significant tax reductions for some at the expense of higher taxes for new property owners. Under current conditions, fewer voters have immediate losses resulting from a change in the law, and its repeal would avoid potential future distortions.

There are two limitations of this analysis that should be acknowledged. First, due to data limitations the unit of analysis is conducted at the county level and therefore necessarily abstracts from tax base erosion differentials that may exist in more narrowly defined jurisdictions. One advantage of county level data, however, is that we are able to incorporate into the analysis more detailed socio-economic variables that are not available for smaller jurisdictions on an annual basis. A second limitation is that it is possible that assessment growth caps may have a

\footnotetext{
${ }^{28}$ Since 2007, Michigan counties have experienced significant losses in property value and there has been a reversal such that SEV/TV is now decreasing.
} 
capitalization effect on property values, but the direction and degree of capitalization is unclear. For property owners who expect to hold onto their property for many years, the taxable value cap represents a potential long-run benefit: They may pay higher taxes today, but tax liabilities are guaranteed to grow at the rate of inflation and will not exceed five percent. ${ }^{29}$ The capitalization of tax payments, including lower future payments, for the duration of tenure in the home may lead to a higher willingness to pay for such property owners. However, for property owners who do not expect to hold on to property for an extended number of years or are not able to anticipate how long he or she may own property, the taxable value growth cap merely represents higher overall tax prices (O’Sullivan, Sexton, and Sheffrin, 1995). These property owners may very well be willing to pay less for property under the taxable value growth cap. In addition, if mobility is reduced because of the taxable value growth cap as suggested by previous studies, fewer homes might be available on the market and this may lead to higher housing prices. It should also be noted that because of the Headlee revenue growth limit, it is likely that the overall revenue growth and thus average tax prices would not be significantly different in the absence of the taxable value cap.

Despite these limitations, the current work provides new evidence regarding the implications of tax base erosion, emerging differential in tax prices between potential new property owners and long-time property owners and in-migration. Future work aimed at explicitly identifying the implications of the taxable value cap on the redistribution of property tax payments across demographic groups will be a valuable contribution.

\footnotetext{
${ }^{29}$ In an environment of rising home values, this may be very comforting. However, recently home values have actually fallen, and taxable values are by law increasing by the rate of inflation. An exception is for homeowners whose state equalized value no longer exceeds taxable value: For these properties, taxable value falls with state equalized value.
} 


\section{References}

Anderson, Nathan B., and Therese J. McGuire. 2007. “An Unfettered Property Tax in Illinois,” Working Paper.

Bertrand, Marianne, Esther Duflo and Sendhil Mullainathan. 2004. "How Much Should we Trust Difference-in-Difference Estimators?” Quarterly Journal of Economics, 119, 1: 249-75

Bowman, John H. 2006. "Property Tax Policy Responses to Rapidly Rising Home Values:

District of Columbia, $\quad$ Maryland, and Virginia." National Tax Journal, LIX.3: 717-33.

Cebula, Richard J. 1990. "A Brief Empirical Note on the Tiebout Hypothesis and State Income Tax Policies,” Public Choice, 67 (1): 87-89.

Cebula, Richard J. and Gigi M. Alexander. 2006. "Determinants of Net Interstate Migration, 2000-2004,” Journal of Regional Analysis and Policy, 36 (2): 116-123.

Citizens Research Council. 2001. CRC Memorandum Number 1058: “The Growing Difference between State Equalized Value and Taxable Value in Michigan,” Livonia, Michigan: Citizens Research Council.

Clark, David E., Thomas A. Knapp and Nancy E. White. 1996. "Personal and Location-Specific Characteristics and Elderly Interstate Migration,” Growth and Change, 27: 327-351.

Conway, Karen S. and Andrew J. Houtenville. 1998. "Do the Elderly Vote with Their Feet”? Public Choice 97, (1): 63-85.

Conway, Karen S. and Andrew J. Houtenville. 2001. "Elderly Migration and State Fiscal Policy: Evidence from the 1990 Census Migration Flows,” National Tax Journal, 54 (1): 103-123.

Conway, Karen S, and Jonathon Rork. 2006. "State" Death" Taxes and Elderly Migration-The Chicken or the Egg?” National Tax Journal, 59 (1): 97-128.

Dye, Richard F., Therese J. McGuire, and Daniel P. McMillen. 2005. “Are Property Tax Limitations more binding over time?” National Tax Journal, 58(2): 215-25.

Dye, Richard F. and Daniel P. McMillen. 2007. “The Algebra of Tax Burden Shifts from Assessment Limitations”. Lincoln Institute of Land Policy.

Dye, Richard F., Daniel P. McMillen, and David F. Merriman. 2006. "Illinois' Response to Rising Residential Property Values: An Assessment Growth Cap in Cook County." National Tax Journal, LIX.3: 707-16.

Feldman, Naomi E., Paul N. Courant, and Douglas Drake. 2003. “The Property Tax in Michigan.” in Michigan at the Millennium, edited by Charles L. Ballard, Paul N. Courant, Douglas C. Drake, Ronald C. Fisher, and Elisabeth R. Gerber. East Lansing: Michigan State University Press, 577-602.

Farnham, Martin and Purvi Sevak. 2002. "Local Fiscal Policy and Retiree Migration: Evidence from the Health and Retirement Study," Hunter College Department of Economics Working Papers 02/7, Hunter College, Department of Economics. 
Ferreira, Fernando. 2004. "You Can Take It with You: Transferability of Proposition 13 Tax Benefits, Residential Mobility, and Willingness to Pay for Housing Amenities.” Working Paper 72, Center for Labor Economics, University of California, Berkeley.

Giertz, J Fred. 2006. "The Property Tax Bound." National Tax Journal, LIX.3: 695-705.

Haveman, Mark, and Terri Sexton. 2008. "Property Tax Assessment Limits: Lessons from Thirty Years of Experience.” Lincoln Institute of Land Policy.

Kezdi, Gabor. 2004. "Robust Standard-Error Estimations in Fixed-Effect Panel Models.” Hungarian Statistical Review, 9: 95-116

Muhammad, Daniel. 2007. "Horizontal Inequity, Vertical Inequity and the District of Columbia's Property Assessment Limitation.” Presented at the National Tax Association's $100^{\text {th }}$ Annual Conference on Taxation.

Mullins, Daniel R. and Philip G. Joyce. 1996. "Tax and Expenditure Limitations and State Fiscal Structure: An Empirical Assessment,” Public Budgeting and Finance, 16: 75-101.

Nagy, John. 1997. "Did Proposition 13 Affect the Mobility of California Homeowners”? Public Finance Review, 25 (1): 102-116.

O’Sullivan, Arthur, Terri A. Sexton and Steven M. Sheffrin. 1995. "Property Taxes, Mobility and Home Ownership,” Journal of Urban Economics, 37: 107-129.

Skidmore, Mark. 1999. “Tax and expenditure limitations and the fiscal relationships between state and local governments, Public Choice, 99(1/2): 77-102.

Wasi, Nada and Michelle J. White. 2005. "Property Tax Limitations and Mobility: Lock-in Effect of California’s Proposition 13,” Brookings-Wharton Papers on Urban Affairs: 2005: 59-97.

Youngman, Joan. "The Variety of Property Tax Limits: "Goals, Consequences, and Alternatives.” State Tax Notes, November, (2007): 541-57.

Yu, Eunice, and Jianguo Liu. 2007. "Environment Impacts of Divorce." PNAS, 104.51: 2062934. 
Figure 1

Ratio of State Equalized Value to Taxable Value, 2006

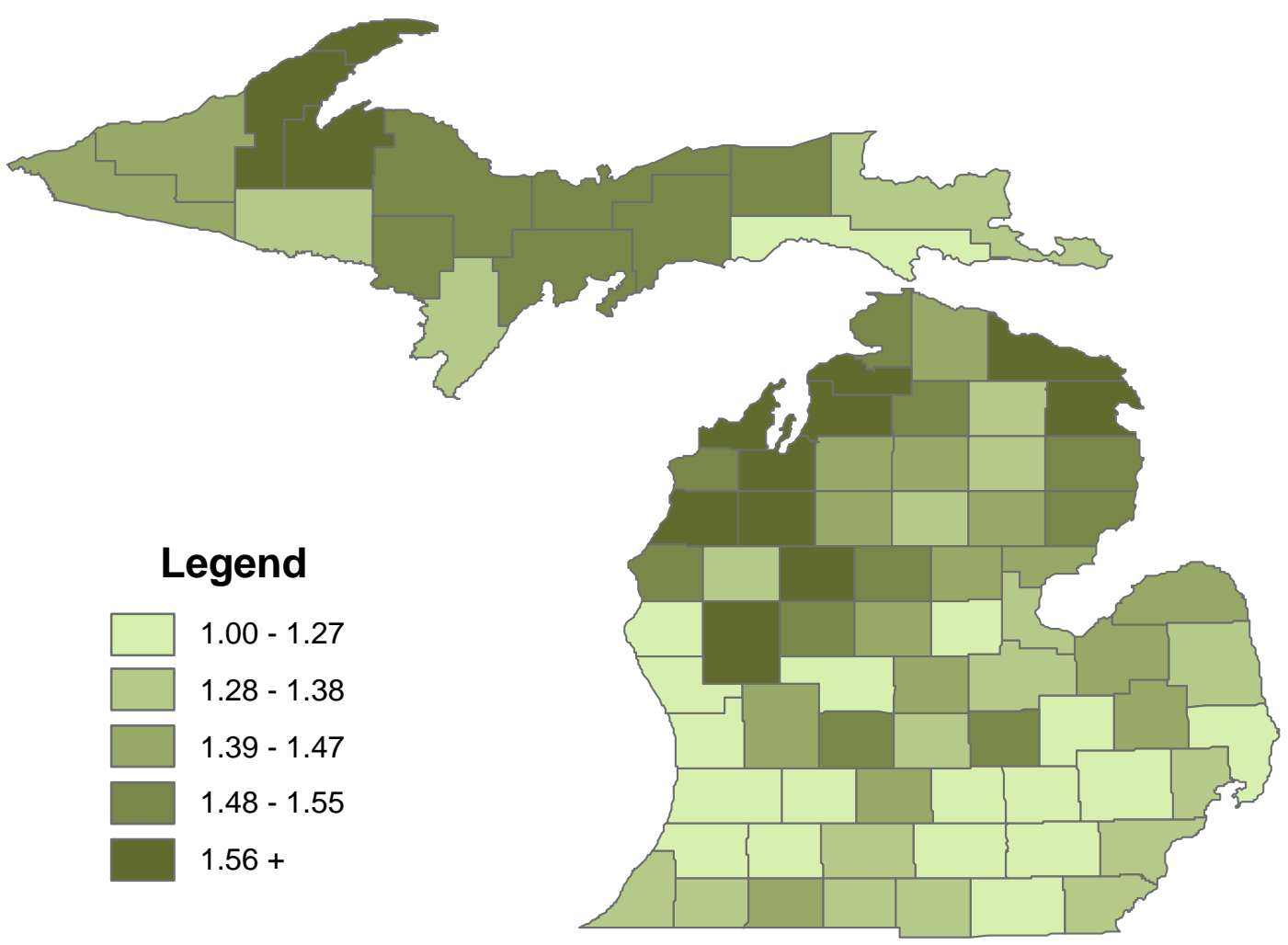

Source: State of Michigan Department of Treasury. 


\section{Table 1}

Average Statewide Millage Rates

$\begin{array}{cccc}\begin{array}{c}\text { Calendar } \\ \text { Year }\end{array} & \begin{array}{c}\text { Homestead } \\ \text { Property }\end{array} & \begin{array}{c}\text { Nonhomestead } \\ \text { Property }\end{array} & \begin{array}{c}\text { All } \\ \text { Property }\end{array} \\ 1990 & 57.17 & 57.17 & 57.17 \\ 1991 & 57.34 & 57.34 & 57.34 \\ 1992 & 58.09 & 58.09 & 58.09 \\ 1993 & 56.64 & 56.64 & 56.64 \\ 1994 & 30.22 & 48.17 & 38.19 \\ 1995 & 31.00 & 48.79 & 38.88 \\ 1996 & 31.36 & 49.54 & 39.32 \\ 1997 & 31.36 & 49.63 & 39.25 \\ 1998 & 31.43 & 49.68 & 39.27 \\ 1999 & 31.40 & 49.76 & 39.16 \\ 2000 & 31.54 & 50.10 & 39.32 \\ 2001 & 32.12 & 50.72 & 39.78 \\ 2002 & 32.60 & 51.00 & 40.17 \\ 2003 & 31.52 & 50.06 & 39.00 \\ 2004 & 32.70 & 51.20 & 40.00 \\ 2005 & 32.60 & 51.38 & 39.88 \\ 2006 & 32.66 & 51.38 & 39.96\end{array}$

Source: All Property Millage Rates from State Tax Commission except 1994; CY 1994 All Property Rate and Homestead and Non-homestead millage rates from the Tax Analysis Division, Michigan Department of Treasury. 
Table 2

Summary Statistics about Michigan Counties

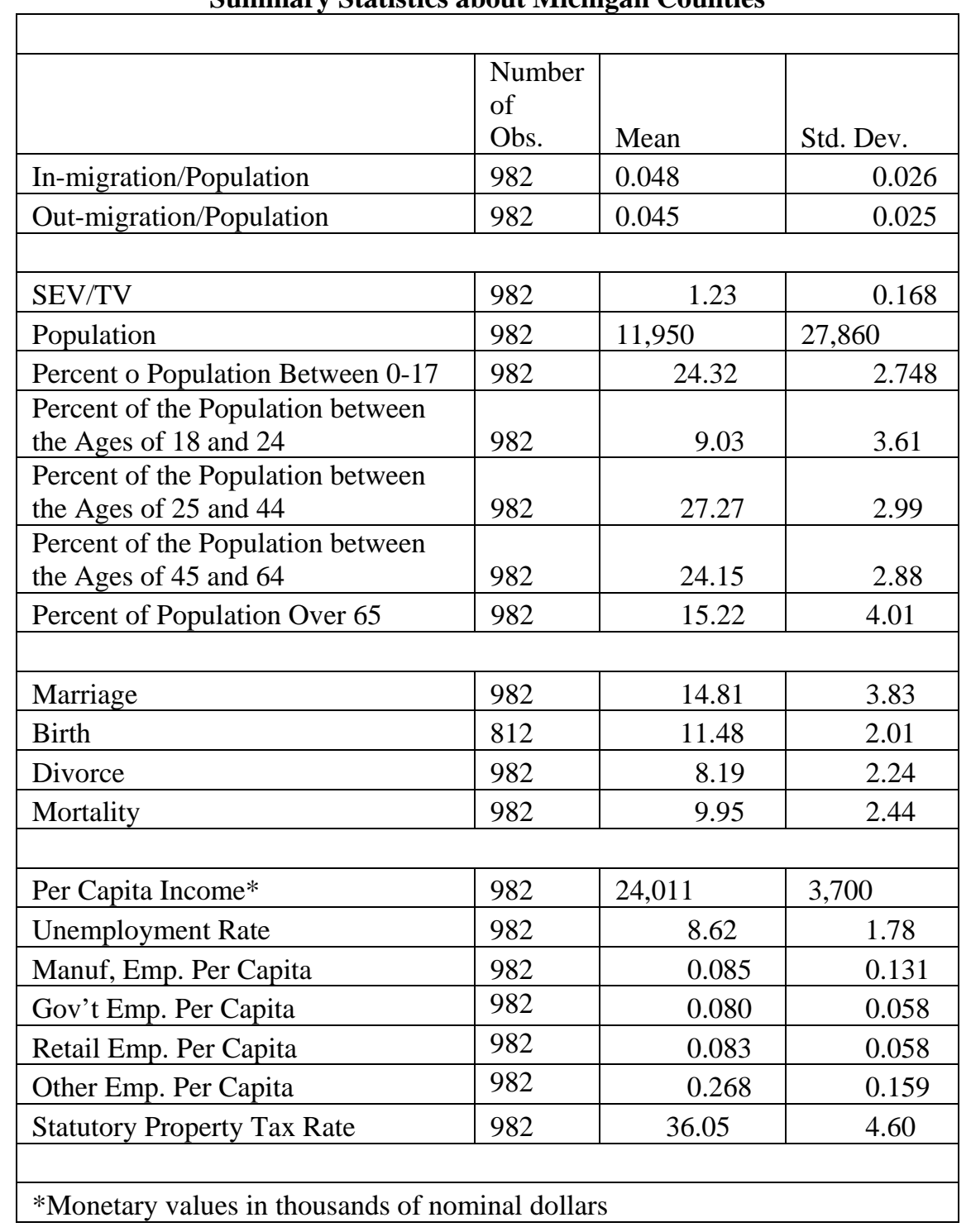


Table 3

In-migration Regression Results

(t-statistics or $\mathrm{z}$-statistics in parentheses)

\begin{tabular}{|c|c|c|c|c|c|c|c|c|}
\hline \multirow[b]{2}{*}{ Independent Variable } & \multicolumn{8}{|c|}{ Dependent Variable: In-migration Rate } \\
\hline & $\begin{array}{l}\text { OLS Fixed } \\
\text { Effects } \\
\text { Cluster } \\
(1)\end{array}$ & $\begin{array}{c}\text { OLS Fixed } \\
\text { Effects } \\
\text { Cluster } \\
(2)\end{array}$ & $\begin{array}{c}\text { OLS Fixed } \\
\text { Effects } \\
\text { Cluster } \\
\text { (3) }\end{array}$ & $\begin{array}{c}\text { OLS Fixed } \\
\text { Effects } \\
\text { Cluster } \\
\text { (4) }\end{array}$ & $\begin{array}{c}\text { 2SLS Fixed } \\
\text { Effects } \\
\text { Cluster }^{\mathrm{a}} \\
\text { (5) }\end{array}$ & $\begin{array}{c}\text { 2SLS Fixed } \\
\text { Effects } \\
\text { Cluster }^{\mathrm{a}} \\
\text { (6) }\end{array}$ & $\begin{array}{c}\text { 2SLS Fixed } \\
\text { Effects } \\
\text { Cluster }^{\mathrm{a}} \\
\text { (7) }\end{array}$ & $\begin{array}{c}\text { 2SLS Fixed } \\
\text { Effects } \\
\text { Cluster }^{\mathrm{a}} \\
\text { (8) }\end{array}$ \\
\hline Ln(SEV/TV) & $\begin{array}{c}-0.04 * * * \\
(-3.208)\end{array}$ & $\begin{array}{c}-0.03^{*} \\
(-1.723)\end{array}$ & $\begin{array}{c}-0.06 * * * \\
(-2.699)\end{array}$ & $\begin{array}{c}-0.04 \\
(-1.305)\end{array}$ & $\begin{array}{l}-0.20 * * \\
(-2.391)\end{array}$ & $\begin{array}{c}-0.12 * \\
(-1.927)\end{array}$ & $\begin{array}{c}-0.22 * \\
(-1.663)\end{array}$ & $\begin{array}{c}-0.14 \\
(-1.444)\end{array}$ \\
\hline Ln(Per Capita Income) & $\begin{array}{c}0.04071^{* * *} \\
(3.001)\end{array}$ & $\begin{array}{c}0.07452^{* * *} \\
(3.980)\end{array}$ & $\begin{array}{c}0.08316^{* * *} \\
(2.887)\end{array}$ & $\begin{array}{c}0.12189 * * * \\
(3.106)\end{array}$ & $\begin{array}{c}0.10187 * * \\
(2.397)\end{array}$ & $\begin{array}{c}0.07865^{* * *} \\
(4.208)\end{array}$ & $\begin{array}{c}0.08054^{*} \\
(1.708)\end{array}$ & $\begin{array}{c}0.04447^{* * *} \\
(3.691)\end{array}$ \\
\hline Unemployment Rate & $\begin{array}{c}-0.001 * * \\
(-2.528) \\
\end{array}$ & $\begin{array}{l}-0.001^{*} \\
(-1.892) \\
\end{array}$ & $\begin{array}{c}-0.001 \\
(-1.367) \\
\end{array}$ & $\begin{array}{c}-0.001 \\
(-1.496) \\
\end{array}$ & $\begin{array}{c}-0.002 * * * \\
(-3.216) \\
\end{array}$ & $\begin{array}{l}-0.001^{*} \\
(-1.845) \\
\end{array}$ & $\begin{array}{c}-0.001 \\
(-1.212) \\
\end{array}$ & $\begin{array}{c}0.000 \\
(0.263) \\
\end{array}$ \\
\hline Ln(Manuf. Emp. Per Capita) & $\begin{array}{c}0.001 \\
(0.282)\end{array}$ & $\begin{array}{c}-0.002 \\
(-0.701)\end{array}$ & $\begin{array}{c}-0.004 \\
(-0.857)\end{array}$ & $\begin{array}{c}-0.006 \\
(-1.135)\end{array}$ & $\begin{array}{c}-0.008 \\
(-1.399)\end{array}$ & $\begin{array}{c}-0.005 \\
(-1.576)\end{array}$ & $\begin{array}{c}-0.006 \\
(-1.178)\end{array}$ & $\begin{array}{c}-0.002 \\
(-0.846)\end{array}$ \\
\hline Ln(Gov’t Emp. Per Capita) & $\begin{array}{c}0.004 \\
(0.513)\end{array}$ & $\begin{array}{c}0.000 \\
(0.00680)\end{array}$ & $\begin{array}{c}-0.010 \\
(-0.664)\end{array}$ & $\begin{array}{c}-0.011 \\
(-0.753)\end{array}$ & $\begin{array}{c}0.012 \\
(0.950)\end{array}$ & $\begin{array}{c}0.003 \\
(0.322)\end{array}$ & $\begin{array}{c}0.011 \\
(0.541)\end{array}$ & $\begin{array}{c}-0.005 \\
(-0.435)\end{array}$ \\
\hline Ln(Retail Emp. Per Capita) & $\begin{array}{c}-0.008 * * \\
(-2.545)\end{array}$ & $\begin{array}{c}-0.005 \\
(-1.000)\end{array}$ & $\begin{array}{c}-0.011 * * \\
(-2.257)\end{array}$ & $\begin{array}{c}-0.010 \\
(-1.526)\end{array}$ & $\begin{array}{c}-0.014 * * * \\
(-3.731)\end{array}$ & $\begin{array}{c}-0.009 * * \\
(-2.233)\end{array}$ & $\begin{array}{c}-0.004 \\
(-1.217)\end{array}$ & $\begin{array}{c}0.000 \\
(0.0899)\end{array}$ \\
\hline Ln(Other Emp. Per Capita) & $\begin{array}{c}-0.020 * * * \\
(-3.200) \\
\end{array}$ & $\begin{array}{c}-0.023^{* * *} \\
(-2.922) \\
\end{array}$ & $\begin{array}{c}-0.024 * * \\
(-2.277) \\
\end{array}$ & $\begin{array}{c}-0.023^{*} \\
(-1.812) \\
\end{array}$ & $\begin{array}{c}-0.019 * * * \\
(-3.074) \\
\end{array}$ & $\begin{array}{c}-0.020 * * * \\
(-4.105) \\
\end{array}$ & $\begin{array}{c}-0.010 \\
(-1.351) \\
\end{array}$ & $\begin{array}{c}-0.003 \\
(-0.448) \\
\end{array}$ \\
\hline Ln(Age under 18) & $\begin{array}{c}0.016 \\
(1.015)\end{array}$ & $\begin{array}{c}0.005 \\
(0.285)\end{array}$ & $\begin{array}{c}0.044 \\
(0.735)\end{array}$ & $\begin{array}{c}-0.069 \\
(-0.981)\end{array}$ & $\begin{array}{c}-0.063 \\
(-1.133)\end{array}$ & $\begin{array}{l}-0.062 * \\
(-1.776)\end{array}$ & $\begin{array}{c}0.071 \\
(1.435)\end{array}$ & $\begin{array}{c}-0.095^{* *} \\
(-2.233)\end{array}$ \\
\hline Ln(Age 18-24) & $\begin{array}{c}-0.008 \\
(-0.873) \\
\end{array}$ & $\begin{array}{c}-0.007 \\
(-0.743) \\
\end{array}$ & $\begin{array}{c}-0.011 \\
(-0.464)\end{array}$ & $\begin{array}{c}-0.013 \\
(-0.644)\end{array}$ & $\begin{array}{c}0.031 \\
(1.170) \\
\end{array}$ & $\begin{array}{c}0.001 \\
(0.0765) \\
\end{array}$ & $\begin{array}{c}0.045 \\
(1.026)\end{array}$ & $\begin{array}{c}-0.017 \\
(-1.147)\end{array}$ \\
\hline Ln(Age 25-44) & $\begin{array}{c}0.006 \\
(0.353)\end{array}$ & $\begin{array}{c}0.026 \\
(1.465)\end{array}$ & $\begin{array}{c}-0.016 \\
(-0.490)\end{array}$ & $\begin{array}{c}-0.057 \\
(-1.433)\end{array}$ & $\begin{array}{c}0.025 \\
(0.604)\end{array}$ & $\begin{array}{c}0.010 \\
(0.356)\end{array}$ & $\begin{array}{c}-0.029 \\
(-0.697)\end{array}$ & $\begin{array}{c}-0.070 * * * \\
(-2.678)\end{array}$ \\
\hline Ln(Age 45- 64) & $\begin{array}{c}-0.011 \\
(-0.712) \\
\end{array}$ & $\begin{array}{l}0.036^{* *} \\
(2.103) \\
\end{array}$ & $\begin{array}{c}-0.030 \\
(-0.618) \\
\end{array}$ & $\begin{array}{c}-0.017 \\
(-0.391) \\
\end{array}$ & $\begin{array}{c}0.022 \\
(0.670) \\
\end{array}$ & $\begin{array}{c}0.006 \\
(0.166) \\
\end{array}$ & $\begin{array}{c}0.044 \\
(0.703) \\
\end{array}$ & $\begin{array}{l}-0.094^{*} \\
(-1.937) \\
\end{array}$ \\
\hline Adjusted $\mathrm{R}^{2}$ & 0.904 & 0.908 & 0.920 & 0.923 & -0.121 & 0.383 & -0.791 & 0.002 \\
\hline Time Indicator Variables & No & Yes & No & Yes & No & Yes & No & Yes \\
\hline County-specific Time Trend & No & No & Yes & Yes & No & No & Yes & Yes \\
\hline $\mathrm{N}$ & 982 & 982 & 982 & 982 & 812 & 812 & 812 & 812 \\
\hline
\end{tabular}




\begin{tabular}{|c|c|c|c|c|}
\hline \multicolumn{5}{|c|}{$\begin{array}{c}\text { Appendix A } \\
\text { Tax Base Erosion Regression Results } \\
\text { (t-statistics or z-statistics in parentheses) }\end{array}$} \\
\hline & \multicolumn{4}{|c|}{ Dependent Variable: Ln(SEV/TV) } \\
\hline Independent Variable & $\begin{array}{c}\text { OLS Fixed } \\
\text { Effects Cluster } \\
(1)\end{array}$ & $\begin{array}{c}\text { OLS Fixed } \\
\text { Effects Cluster } \\
(2)\end{array}$ & $\begin{array}{c}\text { OLS Fixed } \\
\text { Effects Cluster } \\
\text { (3) }\end{array}$ & $\begin{array}{c}\text { OLS Fixed } \\
\text { Effects Cluster } \\
(4)\end{array}$ \\
\hline Ln(Per Capita Income) & $\begin{array}{c}0.46^{* * *} \\
(6.221)\end{array}$ & $\begin{array}{c}0.11 \\
(1.054)\end{array}$ & $\begin{array}{l}0.30 * * \\
(2.470)\end{array}$ & $\begin{array}{c}0.01 \\
(0.104)\end{array}$ \\
\hline Unemployment Rate & $\begin{array}{c}-0.00637^{* * * *} \\
(-2.859)\end{array}$ & $\begin{array}{c}-0.00729 * * * \\
(-2.639)\end{array}$ & $\begin{array}{c}-0.00228 \\
(-1.087)\end{array}$ & $\begin{array}{c}-0.00033 \\
(-0.140)\end{array}$ \\
\hline Ln(Manuf. Emp. Per Capita) & $\begin{array}{l}-0.038^{*} \\
(-1.710)\end{array}$ & $\begin{array}{c}-0.018 \\
(-0.866)\end{array}$ & $\begin{array}{l}-0.033^{*} \\
(-1.972)\end{array}$ & $\begin{array}{c}-0.011 \\
(-0.689)\end{array}$ \\
\hline Ln(Gov’t Emp. Per Capita) & $\begin{array}{c}0.063 \\
(1.179)\end{array}$ & $\begin{array}{c}0.053 \\
(1.218)\end{array}$ & $\begin{array}{c}0.073 \\
(1.244)\end{array}$ & $\begin{array}{c}-0.010 \\
(-0.184)\end{array}$ \\
\hline Ln(Retail Emp. Per Capita) & $\begin{array}{c}-0.043^{* *} \\
(-2.350)\end{array}$ & $\begin{array}{c}-0.005 \\
(-0.187)\end{array}$ & $\begin{array}{c}-0.005 \\
(-0.419)\end{array}$ & $\begin{array}{c}0.009 \\
(0.416)\end{array}$ \\
\hline Ln(Other Emp. Per Capita) & $\begin{array}{c}0.010 \\
(0.311)\end{array}$ & $\begin{array}{c}0.007 \\
(0.236)\end{array}$ & $\begin{array}{c}-0.031 \\
(-1.219)\end{array}$ & $\begin{array}{c}-0.010 \\
(-0.354)\end{array}$ \\
\hline Ln(Age under 18) & $\begin{array}{c}-0.430 * * \\
(-2.533)\end{array}$ & $\begin{array}{c}-0.360 * * \\
(-2.355)\end{array}$ & $\begin{array}{c}0.172 \\
(0.498)\end{array}$ & $\begin{array}{c}-0.038 \\
(-0.169)\end{array}$ \\
\hline Ln(Age 18-24) & $\begin{array}{c}0.286^{* * *} \\
(3.555)\end{array}$ & $\begin{array}{l}0.145^{* *} \\
(2.207)\end{array}$ & $\begin{array}{c}0.336 * * * \\
(3.706)\end{array}$ & $\begin{array}{c}0.092 \\
(1.212)\end{array}$ \\
\hline Ln(Age 25-44) & $\begin{array}{c}0.282 \\
(1.360)\end{array}$ & $\begin{array}{c}0.116 \\
(0.561)\end{array}$ & $\begin{array}{c}-0.080 \\
(-0.313)\end{array}$ & $\begin{array}{c}-0.005 \\
(-0.0211)\end{array}$ \\
\hline Ln(Age 45- 64) & $\begin{array}{c}0.233 \\
(1.383) \\
\end{array}$ & $\begin{array}{l}-0.363^{*} \\
(-1.939) \\
\end{array}$ & $\begin{array}{c}0.350 \\
(1.621) \\
\end{array}$ & $\begin{array}{l}-0.329 * \\
(-1.688) \\
\end{array}$ \\
\hline Ln(Marriage) & $\begin{array}{c}-0.025 \\
(-1.636)\end{array}$ & $\begin{array}{c}-0.023 * * \\
(-2.135)\end{array}$ & $\begin{array}{c}-0.015 \\
(-1.295)\end{array}$ & $\begin{array}{c}-0.018 * * \\
(-2.021)\end{array}$ \\
\hline Ln(Birth) & $\begin{array}{c}-0.045^{* *} \\
(-2.099) \\
\end{array}$ & $\begin{array}{c}-0.051 * * * \\
(-2.767)\end{array}$ & $\begin{array}{c}-0.018 \\
(-1.138)\end{array}$ & $\begin{array}{c}-0.004 \\
(-0.309)\end{array}$ \\
\hline Ln(Divorce) & $\begin{array}{c}-0.005 \\
(-0.890) \\
\end{array}$ & $\begin{array}{c}-0.008 \\
(-1.571) \\
\end{array}$ & $\begin{array}{c}0.000 \\
(0.0732)\end{array}$ & $\begin{array}{c}-0.003 \\
(-0.697) \\
\end{array}$ \\
\hline Ln(Mortality) & $\begin{array}{c}-0.013 \\
(-0.644)\end{array}$ & $\begin{array}{c}0.002 \\
(0.0853)\end{array}$ & $\begin{array}{c}-0.016 \\
(-1.039)\end{array}$ & $\begin{array}{c}0.013 \\
(1.059)\end{array}$ \\
\hline Adjusted $\mathrm{R}^{2}$ & 0.931 & 0.950 & 0.975 & 0.983 \\
\hline Time Indicator Variables & No & Yes & No & Yes \\
\hline County-specific Time Trend & No & No & Yes & Yes \\
\hline $\mathrm{N}$ & 812 & 812 & 812 & 812 \\
\hline
\end{tabular}


Variables

In-migration

Out-migration

SEV

TV

$\mathrm{SEV} / \mathrm{TV}$

Population

Percent of Population

Between 0-17

Percent of Population

between 18-24

Percent of Population

between 25-44

Percent of Population

between 45-64

Percent of Population Over

65

Marriage

Birth

Divorce

Mortality

Per Capita Income Unemployment Rate

Manuf, Emp. Per Capita

Gov’t Emp. Per Capita

Retail Emp. Per Capita

Other Emp. Per Capita

Per Capita New

Construction

Statutory Property Tax

Rate $=$ Effective Rate for

New Resident

\section{Appendix B \\ Definitions and Sources of Variables \\ Definitions}

Migration into a county (based on tax return

data)/population

Migration out of a county (based on tax return

data)/population

County aggregate state equalized value, which is equal $1 / 2$

of estimated market value

County aggregate taxable value which is allowed to grow

at the rate of inflation unless a property is sold (selling

property returns taxable value to state equalized value)

Ratio of aggregate state equalized value to aggregate

taxable value in the county

County population plus in-migration minus out-migration

Percent of the population between the ages of zero and 17

Percent of the population between the ages of 18 and 24

Percent of the population between the ages of 25 and 44

Percent of the population between the ages of 45 and 64

Percent of the population aged 65 and older

Marriage rate per 1,000 population

Birth rate per 1,000 population

Divorce rate per 1,000 population

Mortality rate per 1,000 population

Per capita income

The rate of unemployment

Employment in manufacturing per capita

Employment in government per capita

Employment in retail per capita

Employment in all other categories per capita

The value of new construction per capita

Average statutory rate in the county for all overlying taxing jurisdictions (township, village, city, community college, and county)
Source

CENSUS

and SOI

CENSUS

and SOI

MDT

MDT

MDT

CENSUS

and SOI

CENSUS

CENSUS

CENSUS

CENSUS

CENSUS

$\mathrm{MDCH}$

$\mathrm{MDCH}$

$\mathrm{MDCH}$

$\mathrm{MDCH}$

BEA

BEA

BEA

BEA

BEA

BEA

BEA

MDT

\section{Sources:}

BEA: Bureau of Economic Analysis, Regional Accounts Data: http://www.bea.doc.gov/bea/regional/reis/ CENSUS: U.S. Census Bureau, County Population Estimates: http://eire.census.gov/popest/estimates.php MDT: Michigan Department of Treasury

MDCH: Michigan Department of Community Health

SOI: Statistics of Income, Internal Revenue Service, US Federal Government ${ }^{30}$

\footnotetext{
${ }^{30}$ The Internal Revenue Service collects detailed annual information on the number of in-migrants and outmigrants by county on an annual basis. These data are based on address and changes provided by tax filers.
} 
Appendix C

Out-migration Regression Results

(t-statistics or z-statistics in parentheses)

\begin{tabular}{|c|c|c|c|c|c|c|c|c|}
\hline \multirow[b]{2}{*}{ Independent Variable } & \multicolumn{8}{|c|}{ Dependent Variable: Out-migration Rate } \\
\hline & $\begin{array}{c}\text { OLS Fixed } \\
\text { Effects } \\
\text { Cluster } \\
(1)\end{array}$ & $\begin{array}{c}\text { OLS Fixed } \\
\text { Effects } \\
\text { Cluster } \\
(2)\end{array}$ & $\begin{array}{c}\text { OLS Fixed } \\
\text { Effects } \\
\text { Cluster } \\
(3)\end{array}$ & $\begin{array}{c}\text { OLS Fixed } \\
\text { Effects } \\
\text { Cluster } \\
(4)\end{array}$ & $\begin{array}{c}\text { 2SLS Fixed } \\
\text { Effects } \\
\text { Cluster }^{\mathrm{a}} \\
(5)\end{array}$ & $\begin{array}{c}\text { 2SLS Fixed } \\
\text { Effects } \\
\text { Cluster }^{\mathrm{a}} \\
(6)\end{array}$ & $\begin{array}{c}\text { 2SLS Fixed } \\
\text { Effects } \\
\text { Cluster }^{\mathrm{a}} \\
(7)\end{array}$ & $\begin{array}{c}\text { 2SLS Fixed } \\
\text { Effects } \\
\text { Cluster }^{\mathrm{a}} \\
(8)\end{array}$ \\
\hline Ln(SEV/TV) & $\begin{array}{c}-0.00 \\
(-0.193)\end{array}$ & $\begin{array}{c}0.01 \\
(0.648)\end{array}$ & $\begin{array}{c}-0.04 * * \\
(-2.433)\end{array}$ & $\begin{array}{c}-0.03 \\
(-1.055)\end{array}$ & $\begin{array}{c}0.01 \\
(0.217)\end{array}$ & $\begin{array}{c}0.00 \\
(0.0356)\end{array}$ & $\begin{array}{c}-0.05 \\
(-0.691)\end{array}$ & $\begin{array}{c}-0.18 * \\
(-1.705)\end{array}$ \\
\hline Ln(Per Capita Income) & $\begin{array}{c}0.03299 * * \\
(2.589)\end{array}$ & $\begin{array}{c}0.03866^{* * *} \\
(2.344)\end{array}$ & $\begin{array}{c}0.06190 * * \\
(2.331)\end{array}$ & $\begin{array}{c}0.07928^{*} \\
(1.911)\end{array}$ & $\begin{array}{c}0.00996 \\
(0.417) \\
\end{array}$ & $\begin{array}{c}0.03901^{* * *} \\
(4.132)\end{array}$ & $\begin{array}{c}0.00586 \\
(0.212)\end{array}$ & $\begin{array}{c}0.01179 \\
(0.722) \\
\end{array}$ \\
\hline Unemployment Rate & $\begin{array}{l}-0.001^{*} \\
(-1.779)\end{array}$ & $\begin{array}{c}-0.001 \\
(-1.210)\end{array}$ & $\begin{array}{c}-0.000 \\
(-0.0628)\end{array}$ & $\begin{array}{c}-0.000 \\
(-0.201)\end{array}$ & $\begin{array}{c}-0.000 \\
(-0.196)\end{array}$ & $\begin{array}{c}0.000 \\
(0.289)\end{array}$ & $\begin{array}{c}-0.000 \\
(-0.177)\end{array}$ & $\begin{array}{c}0.000 \\
(0.628)\end{array}$ \\
\hline Ln(Manuf. Emp. Per Capita) & $\begin{array}{c}-0.004 \\
(-1.341)\end{array}$ & $\begin{array}{c}-0.004 \\
(-1.527)\end{array}$ & $\begin{array}{c}-0.005 \\
(-1.382)\end{array}$ & $\begin{array}{l}-0.008^{*} \\
(-1.690)\end{array}$ & $\begin{array}{c}-0.002 \\
(-0.588)\end{array}$ & $\begin{array}{l}-0.004^{*} \\
(-1.790)\end{array}$ & $\begin{array}{c}-0.001 \\
(-0.465)\end{array}$ & $\begin{array}{c}-0.004 \\
(-1.262)\end{array}$ \\
\hline Ln(Gov’t Emp. Per Capita) & $\begin{array}{c}0.009 \\
(0.722)\end{array}$ & $\begin{array}{c}0.009 \\
(0.659)\end{array}$ & $\begin{array}{c}0.012 \\
(0.531)\end{array}$ & $\begin{array}{c}0.014 \\
(0.563)\end{array}$ & $\begin{array}{c}-0.003 \\
(-0.373)\end{array}$ & $\begin{array}{c}-0.002 \\
(-0.247)\end{array}$ & $\begin{array}{c}0.008 \\
(0.688)\end{array}$ & $\begin{array}{c}0.004 \\
(0.277)\end{array}$ \\
\hline Ln(Retail Emp. Per Capita) & $\begin{array}{c}-0.003 \\
(-0.762)\end{array}$ & $\begin{array}{c}-0.003 \\
(-0.383)\end{array}$ & $\begin{array}{c}-0.003 \\
(-0.903)\end{array}$ & $\begin{array}{c}-0.007^{*} \\
(-1.683)\end{array}$ & $\begin{array}{c}-0.002 \\
(-0.665)\end{array}$ & $\begin{array}{l}-0.009 * \\
(-1.781)\end{array}$ & $\begin{array}{c}0.003 \\
(0.762)\end{array}$ & $\begin{array}{c}0.002 \\
(0.330)\end{array}$ \\
\hline Ln(Other Emp. Per Capita) & $\begin{array}{c}-0.018 * * \\
(-2.402)\end{array}$ & $\begin{array}{c}-0.020 * * \\
(-2.021)\end{array}$ & $\begin{array}{c}-0.014 \\
(-1.587)\end{array}$ & $\begin{array}{c}-0.016 \\
(-1.323)\end{array}$ & $\begin{array}{c}-0.016^{* *} \\
(-2.249)\end{array}$ & $\begin{array}{c}-0.015^{* *} \\
(-2.239)\end{array}$ & $\begin{array}{c}0.004 \\
(0.503)\end{array}$ & $\begin{array}{c}0.004 \\
(0.433)\end{array}$ \\
\hline Ln(Age under 18) & $\begin{array}{c}0.058 * * * \\
(2.893)\end{array}$ & $\begin{array}{c}0.082^{* *} \\
(2.536)\end{array}$ & $\begin{array}{c}0.011 \\
(0.223)\end{array}$ & $\begin{array}{c}0.043 \\
(0.498)\end{array}$ & $\begin{array}{c}0.040^{* *} \\
(2.048)\end{array}$ & $\begin{array}{c}0.027 \\
(1.354)\end{array}$ & $\begin{array}{c}0.017 \\
(0.435)\end{array}$ & $\begin{array}{c}-0.013 \\
(-0.269)\end{array}$ \\
\hline Ln(Age 18-24) & $\begin{array}{c}0.014 \\
(1.625)\end{array}$ & $\begin{array}{c}0.017^{* *} \\
(2.305)\end{array}$ & $\begin{array}{c}-0.005 \\
(-0.189)\end{array}$ & $\begin{array}{c}0.014 \\
(0.686)\end{array}$ & $\begin{array}{c}-0.002 \\
(-0.0986)\end{array}$ & $\begin{array}{c}0.012 \\
(0.920)\end{array}$ & $\begin{array}{c}0.016 \\
(0.498)\end{array}$ & $\begin{array}{c}0.037^{*} \\
(1.676)\end{array}$ \\
\hline Ln(Age 25-44) & $\begin{array}{c}0.048^{* *} \\
(2.147)\end{array}$ & $\begin{array}{l}0.052^{* *} \\
(2.394)\end{array}$ & $\begin{array}{c}0.092^{* * *} \\
(2.787)\end{array}$ & $\begin{array}{l}0.085^{*} \\
(1.790)\end{array}$ & $\begin{array}{c}0.017 \\
(0.654)\end{array}$ & $\begin{array}{c}0.031 \\
(1.550)\end{array}$ & $\begin{array}{c}0.094^{* * *} \\
(2.773)\end{array}$ & $\begin{array}{c}0.070 \\
(1.400)\end{array}$ \\
\hline Ln(Age 45- 64) & $\begin{array}{c}0.007 \\
(0.432)\end{array}$ & $\begin{array}{c}0.036^{*} \\
(1.848)\end{array}$ & $\begin{array}{c}0.045 \\
(0.843)\end{array}$ & $\begin{array}{c}0.098 * * \\
(2.205)\end{array}$ & $\begin{array}{c}0.002 \\
(0.0784)\end{array}$ & $\begin{array}{c}0.051 * * \\
(2.067)\end{array}$ & $\begin{array}{c}0.075 \\
(1.639)\end{array}$ & $\begin{array}{c}0.041 \\
(0.666)\end{array}$ \\
\hline Adjusted $\mathrm{R}^{2}$ & 0.890 & 0.893 & 0.917 & 0.919 & 0.112 & 0.208 & 0.060 & -0.263 \\
\hline Time Indicator Variables & No & Yes & No & Yes & No & Yes & No & Yes \\
\hline County-specific Time Trend & No & No & Yes & Yes & No & No & Yes & Yes \\
\hline $\mathrm{N}$ & 982 & 982 & 982 & 982 & 812 & 812 & 812 & 812 \\
\hline
\end{tabular}

